\title{
Role of the ICT in Women Empowerment and Achieving SDGs: A Case Study of Developing Countries
}

\author{
Amna Noor ${ }^{1 *} \quad$ Zahid Asghar $^{1} \quad$ Haroon Sarwar ${ }^{2}$ \\ 1.School of Economics, Quai-i-Aazam University, Islamabad, Pakistan \\ 2.Ministry of Development and Reforms, Islamabad Pakistan
}

\begin{abstract}
The aim of the study is to analyze the ways women are empowed through information and communication technology (ICT) and fostering the process of achieving the Sustainable Development Goals (SDGs). Women in developing countries are facing economic and social hardships and have limited access to ICT, which in turn translate into their lack of skills, lower literacy rate and restricted social engagement. Therefore, present study explores the role of ICT on women empowerment in 51 developing countries by conducting dynamic panel data modelling over the period of 2000-17. The study finds that ICT has significant and positive contribution on female labor force participation rate. We have used Generalized Method of Moment (GMM) for handling estimation of dynamic panel data. Control variables like GDP growth and government expenditure on education have positive and statistically significant role to enhance women empowerment. Findings of this study implies that the ICT has an impact on women empowerment and ICT can help in achieving the SDGs related to women empowerment.
\end{abstract}

Keywords: ICT, women, developing countries, empowerment, education, female labor force.

DOI: $10.7176 / \mathrm{JIEA} / 11-1-01$

Publication date: January $31^{\text {st }} 2021$

\section{Introduction}

Information and communication technologies in the last two decades have been recognised as an important indicator for women's empowerment. There is no exact and universal definition of ICT, most of the time it includes all devices, networking components, applications and systems that allow individuals and institutions to act together easily in the digital world like cell phone and internet.

ICT access through mobile phones and broadband has increased more rapidly than those of other technologies. Broadband subscribers increased more than double in eight years it was 527 million in 2010 and in 2018 it became 1.1 billion (GDR 2019). The number of internet users worldwide have increased up to three fold in the last few years, from 1 billion users in 2005 to 3.2 billion users in 2015 (ITU 2017). According to the latest Global Digital Report, the internet users are 4.39 billion while cell phone users are 5.11 billion (GDR 2019). It has been found that 1.3 billion internet users are women as (37\% in whole world are using the Internet), while 1.5 billion men online ( $41 \%$ of all men), which correspond to 200 million fewer women online (World Bank 2016).

International organizations (UN and World Bank) are promoting ICT as a tool for empowering women and ICT is the main attribute of the Sustainable Development Goals. The SDGs have focused on women's empowerment and enhancement of ICTs. The easy and quick access of ICT for women can facilitate and accelerate the achievement of the SDGs. It has been observed that women's use of ICT is greatly lagging behind than that of men in the developing world (Perryman \& Arcos 2016). Therefore, gender inequality is imperative policy concern in the SDGs agenda (Asongu \& Odhiambo 2018). It is important to understand that for the development of a nation, the steps should be taken for women's empowerment.

ICT is one of the fastest ways for empowering historically disadvantaged groups, such as women and minorities (Hafkin \& Huyer, 2006). ICT gives empowerment by giving access to complete information, excellence and reliability of such information help in making decisions (Ogato, 2013). Thus, ICT empowers the women by increasing their purchasing power and by taking decision and control over issues that improve their lives.

Main objective of the study is to find the role of the ICT in enhancing women's empowerment and to enhace the process of achiecing SDGs 2030. We have used dynamic panel data and applied Generalized Method of Moment (GMM) for estimating impact of the ICT on women's empowerment for 51 developing countries over the period 2000-17. The study contributes in existing literature by examining the role of ICT on women's empowerment by focusing on women's empowerment related SDGs specifically goal 4, 5 and 8 .

The goal 4 is to provide quality education and eliminate the gender disparity from education. Goal 5 "gender equality" and its target 5b specifically focus to enhance the use of technology (information and communication technology) for empowerment of women. Goal 8, "Decent work, economic growth and access to technical education," target 8.2 and 8.5 which mentioned in the study achieving development through technological

\footnotetext{
${ }^{1}$ Corresponding author: nooramnaasim@gmail.com

First two authors are from School of Economics Quaid-i-Azam university while third author is from Ministry of Planning, Development and Rforms. Usual disclaimer applies.
} 
upgradation and decent work for all women and men. This study therefore, aims to identify the role of the ICT in women empowerment for fostering SDGs and will also provide policy relevance in achieving the SDGs.

Rest of the study is organized as: Section 2 discusses literature review. The definition of variables and data source are provided in Section 3, while Section 4 represents the methodology, results of the study are mentioned in section 5 and section 6 gives conclusion and recommendations of the study.

\section{Literature Review}

The way ICT has transformed our lives over the period of last two decades have been effectively captured by the global and local literature. ICT related research has given birth to a whole stream of theoretical and interdisciplinary empirical research. A significant part of this literature has tried to assess the economic impact of ICT on women empowerment as well.

ICTs definition and scope has attained different dimensions in the literature. It is like Information Technology (IT), but its main concern is on communication technologies. It is important to note that, ICT not only confined to use computer, internet, cell phones and telephone lines but it is also about information and communication (Dlodlo, 2009). World Bank explains the ICT as it is combination of hardware, software, networks, and media for assemblage, storage, processing program, and demonstration of information in the form of voice, data, text, and description (World Bank, 2016).

ICT has complete variety of electronic technologies and methods used to deal with information and knowledge, as defined by the United Nations Development Program (UNDP) "ICT are basically informationhandling tools - a varied set of goods, applications and services that are used to produce, store, process, distribute and exchange information". ICT are usually referred to assets such as computer and related hardware, software, communication and video equipment (OECD, 2017).

ICT provides people with access to and sharing of information which can increase their capabilities and lead them to empower (Obayelu \& Ogunlade, 2006). According to (Mansell \& Wehn 1998), effective use of ICT has the ability to develop and empower societies through greater inclusion, wellbeing, cooperation and participation. ICT affects quality of life through knowledge, education and skills.

Similar to the ICT there is no worldwide definition of 'empowerment', many authors discuss empowerment in their own way. As Kabeer 1994 defined empowerment as "the expansion in people's ability to make strategic life choices in a context where this ability was previously denied to them". UNICEF (1993) stating that "women's empowerment should be addressed at the level of basic welfare services, access to resources, mobilization and participation, and control over power".

A number of empirical studies are based on measuring ICTs impact on female participation in the labor market and showed that an increase in the use of ICT would in turn increase the participation of female in labor force (Chen, 2004; Beyond Access, 2012; Efobi et al, 2018; Nikulin, 2017; Shehata 2017). Use of the ICT has a positive impact on closing the gender employment gap as ICT has tendency to provide employment opportunities for women (Shehata 2017).

The empowerment of women is not only driven by poverty but also by women's increasing educational attainment and opportunities created in modern countries (Klasen \& Pieters, 2012). ICT is knowledge based, and its entry to labor market is influenced by many aspects, and education is one of the most vital factor in determining access to it labor market. Involvement of the ICT with the support of educational need helps to empower women in the society (Chen 2004).

A number of studies have emphasized the gender empowerment through ICT, which could be in the form of education, knowledge formation and employment (Hafkin, 2000; Chen 2004, Islam 2015). Use of the ICT has the ability to improve women social and economic conditions in developing countries (Asongu \& Odhiambo 2018).

In our study we take empowerment as a process that makes women able to recognize themselves for accomplished task and lead women to capable of decision making choices about their lives in economic, social and cultural aspects.

\section{Data and Definitions of Variables}

In this section, we will discuss the source of data and define the variable. The study analyzes the dynamic panel data of 51 developing countries for the time period 2000-17. The data has been taken from World Development Indicators (WDI) of the World Bank for the ICT indicators and also for control variables.

The study develops ICT index from several ICT access and use indicators. The study use the following indicators to develop the ICT index, mobile phone users per 100 people, internet users per 100 people, fixed broadband subscriber per 100 people and telephone users per 100 people. To convert the ICT indicators into composite index, the study used the weighted average method. We also use different control variables in order to avoid the issue of omitted variable bias. Table 1 presents the detailed definition of all variables. 
Table 1: Definition of Variables:

\begin{tabular}{|c|c|c|c|}
\hline Variables & Symbols & Source & Description \\
\hline \multicolumn{4}{|l|}{ Dependent Variables } \\
\hline $\begin{array}{l}\text { Female labor force } \\
\text { participation }\end{array}$ & FLFP & WDI & $\begin{array}{l}\text { Labor force participation rate of female from the total } \\
\text { working population of age } 15-64 \text {. It is taken as dependent } \\
\text { variable. }\end{array}$ \\
\hline \multicolumn{4}{|l|}{$\begin{array}{l}\text { Main variable of } \\
\text { interest }\end{array}$} \\
\hline ICT index & ICT_index & WD & $\begin{array}{l}\text { Which combines } \\
\text { i) the Internet users per } 100 \text { person who have access the } \\
\text { worldwide networking, } \\
\text { ii) mobile phone users per } 100 \text { person, } \\
\text { iii) telephone main line users per } 100 \text { person by connecting } \\
\text { a customer's equipment to the public network and } \\
\text { iv) the fixed broadband subscribers per } 100 \text { person. }\end{array}$ \\
\hline GDP & GDP & WDI & $\begin{array}{l}\text { GDP growth rate is taken as the proxy for economic } \\
\text { development }\end{array}$ \\
\hline $\begin{array}{l}\text { Gross fixed capital } \\
\text { formation }\end{array}$ & GFCF & WDI & $\begin{array}{l}\text { Gross capital formation (annual growth rate is a measure of } \\
\text { investment }\end{array}$ \\
\hline Fertility rate & FR & WDI & Fertility rate total (birth per women) \\
\hline Urban ratio & UR & WDI & Urban Population divided by total Population \\
\hline $\begin{array}{l}\text { General government } \\
\text { expenditure }\end{array}$ & GCE & WDI & $\begin{array}{l}\text { General government final consumption expenditure (annual } \\
\text { growth rate) }\end{array}$ \\
\hline $\begin{array}{l}\text { Government } \\
\text { expenditure } \\
\text { education }\end{array}$ & GEE & WDI & Government expenditure on education (annual growth rate) \\
\hline Trade openness & TO & WDI & Import plus export divided by GDP growth \\
\hline
\end{tabular}

Table 2 shows descriptive statistics of the given variables. Summary statistics show that almost $46 \%$ of the women in the given countries participate in the labor force. Across countries variation in labor force is $15 \%$. Average ICT index is 25.81 and across country variation is $17 \%$.

Table 2: Descriptive Statistics

\begin{tabular}{|lrrrrr|}
\hline Varia-ble & Obs & \multicolumn{2}{c}{ Mean } & \multicolumn{1}{c}{ Std.Dv } & \multicolumn{1}{c|}{ Min } \\
\hline Flfpr & 918 & 45.82 & 15.044 & 11.893 & 81.841 \\
ICT & 918 & 25.812 & 17.526 & 0.167 & 70.966 \\
GDP & 918 & 4.344 & 3.368 & -14.759 & 18.287 \\
Fr & 918 & 2.622 & 0.975 & 1.085 & 5.58 \\
Ur & 918 & 0.552 & 0.194 & 0.182 & 0.988 \\
Gfcf & 918 & 6.027 & 13.15 & -41 & 57.964 \\
Gce & 918 & 4.395 & 6.643 & -23.076 & 85.359 \\
Gee & 918 & 4.394 & 2.023 & 1.012 & 14.059 \\
Trade & 918 & 0.742 & 0.354 & 0.156 & 2.473 \\
\hline
\end{tabular}

Table 3 shows the correlation matrix for all variables used in estimation. Which has been provided the bivariate relationship among the variables. It has been observed that ICT index has positive association with outcome variable. Also the ICT index has significant association with other control variables and there is no multicollinearity obsereved among variables. 
Table 3: Correlation Matrix:

\begin{tabular}{|l|ccccccccc|}
\hline Variables & $\mathbf{1}$ & $\mathbf{2}$ & $\mathbf{3}$ & $\mathbf{4}$ & $\mathbf{5}$ & $\mathbf{6}$ & $\mathbf{7}$ & $\mathbf{8}$ & $\mathbf{9}$ \\
\hline Flfpr & 1 & & & & & & & & \\
ICT & 0.047 & 1 & & & & & & & \\
GDP & 0.073 & -0.238 & 1 & & & & & & \\
Fr & 0.032 & -0.445 & 0.036 & 1 & & & & & \\
Ur & -0.044 & 0.423 & -0.218 & -0.464 & 1 & & & & \\
Gfcf & -0.014 & -0.131 & 0.407 & -0.01 & -0.033 & 1 & & & \\
Gce & 0.082 & -0.137 & 0.238 & 0.159 & -0.179 & 0.036 & 1 & & \\
Gee & 0.09 & 0.119 & -0.148 & -0.135 & 0.187 & -0.077 & -0.147 & 1 & \\
Trade & 0.276 & 0.214 & 0.017 & -0.183 & -0.027 & -0.007 & -0.015 & 0.241 & 1 \\
\hline
\end{tabular}

Methodology

To investigate the impact of ICT on women empowerment, most of the studies used OLS, panel GLS and panel IV, ARDL approach and GMM technique (Chen 2004; Islam 2015; Nikulin 2015; Efobi et al 2018; Asongu \& Odhiambo 2018). In current study we used the (Roodman 2009) GMM approach also use by (Asongu \& Odhiambo, 2018). The reason for adopting GMM is that it produces more efficient estimates and avoid the proliferation of instruments and also tackle endogeneity, heterogeneity and over identification issues. Female labor force participation rate is used as dependent variable, while ICT index is our main independent variable which is supported by control variables.

$$
\begin{aligned}
& \text { 1. } F L F P_{i t}=\beta_{1}+\beta_{2} F L F P_{i t-1}+\beta_{3} G D P_{i t}+\beta_{4} I C T_{i t}+\beta_{5} F R_{i t}+\beta_{6} U R_{i t}+\beta_{7} \ln T O_{i t}+\beta_{8} \operatorname{lnGFCF_{it}}+ \\
& \beta_{9} g c e_{i t}+\beta_{10} g e e_{i t}+\varepsilon_{i}+\eta_{t}+\mu_{i t} \\
& \text { 2. } F L F P_{i t}-F L F P_{i t-1}=\beta_{2}\left(F L F P_{i t-1}-F L F P_{i t-2}\right)+\beta_{3}\left(G D P_{i t}-G D P_{i t-1}\right)+\beta_{4}\left(I C T_{i t}-I C T_{i t-1}\right)+ \\
& \left.\beta_{5}\left(F R_{i t}-F R_{i t-1}\right)+\beta_{6}\left(U R_{i t}-U R_{i t-1}\right)+\beta_{7} \operatorname{lnTO}-\operatorname{lnTO} O_{i t-1}\right)+\beta_{8}\left(\ln G F C F_{i t}-\ln G F C F_{i t-1}\right)+ \\
& \beta_{9}\left(g e_{i t}-g c e_{i t-1}\right)+\beta_{10}\left(g e e_{i t}-g e e_{i t-1}\right)+\left(\eta_{t}-\eta_{t-1}\right)+\left(\mu_{i t}-\mu_{i t-1}\right) \\
& \text { Where } \varepsilon_{i} \text { is the country-specific effect, while } \eta_{t} \text { time-specific constant and } \mu_{i t} \text { is the residual of the model. }
\end{aligned}
$$

\section{Estimation Technique}

The current analysis is based on the GMM approach (Roodman 2009). Our purpose of using two differenced GMM approach for our dynamic panel data model is to take care the following issues, firstly number of cross sections are greater than the number of time series, i.e. $\mathrm{N}>\mathrm{T}$ which is $51>18$. Secondly, to handle the endogeneity problem for time invariant omitted variables and simultaneity handled by taking instruments which also control heterogeneity. Thirdly, there should be panel data as for GMM method, which shows that cross-country differences are considered (Asongu and Nwachukwu, 2017; Efobi et al 2018). Fourth, lag value of female labor force participation is consistent over time as the correlation coefficient between the level and first lag of the indicators are higher than 0.8 (Asongu\& Odhiambo 2018).

\section{Results}

In table 4 we have discussed the results of female labor force participation rate measured by two-step difference GMM. The technique has the ability to include more relevant instruments unlike the system GMM.

To ensure the robustness of our results, we have estimated three models by including a set of additional variable to find that our results are consistent. The ICT index is statistically significant with expected sign which implies that ICT has positive impact on female labour force participation rate and can strengthen the efforts for achieving SDGs 5, 4 and 8, if ICT index is increased by 1 unit the female labour force participation rate would increase by 0.037 percent. Although this result shows lower influence but our all three models suggest that the ICT is significant and has positive impact on women empowerment. 
Table 4: Dependent variable: female labor force participation rate

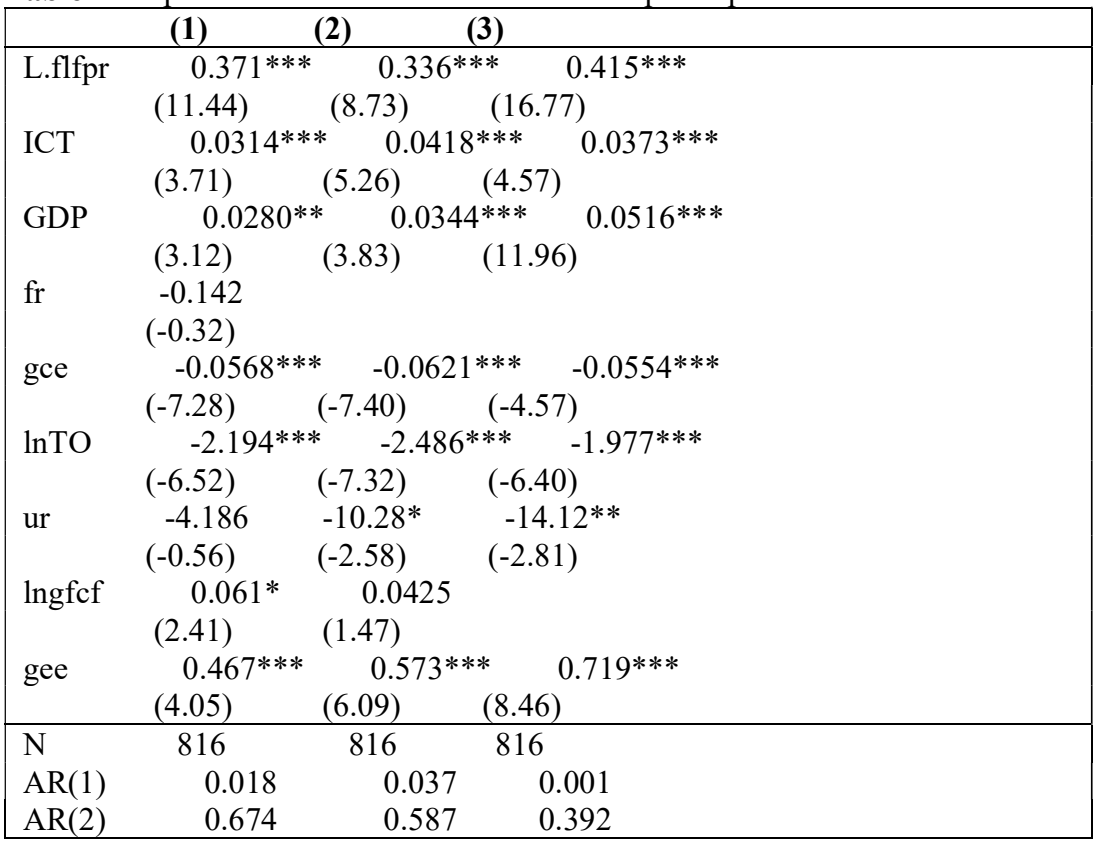

Our results show expected signs of control variables, the positive and significant impact of GDP growth in terms of economic development on women empowerment. The results indicate that economic development is inclusive with respect to women empowerment in developing countries. The government expenditure on education has positive impact on female labor force participation rate and fostering the process of SDGs. GFCF has positive association with women empowerment.

On the other hand, log of trade openness has significant but negative impact on female labour force participation rate which is in case of developing countries maybe the case that more import means less domestic economic activities which in turn implies lower flfpr. Our estimates suggest that, on average, a 1 percent rise in the government final consumption expenditure is associated with about a 0.057 percent reduction in women empowerment in developing countries. While the urban ratio has negative impact on female labour force participation rate.

\section{Conclusion and Recommendations:}

As having almost an equal proportion in terms of population, it is as necessary to highlight the issues to provide suitable solutions for women as for men so that both can contribute towards economic betterment. The ICT has played an important role to empower women over past couple of decades and has a distinctive consideration in setting the SDGs.

The study finds that the ICT has statistically significant and positive impact on women empowerment, which shows that easy access and use of the ICT can improve the female labor force participation rate. Other feature variable like GDP growth rate, government expenditure on education and gross fixed capital formation has also significant and positive impact on women empowerment.

Our finding supports the positive role of the ICT on female labor force participation rate which has implication for the SDGs in many perspective notably, empowering women, enhancing technology, increasing participation of women in labor force and inclusive development and economic growth in developing countries.

It is necessary to make women feel empowered and an important part of the society as women can participate in economic activities but also feel motivated enough that can lead them achieve self-actualization increasing their productivity and fostering the process of achieving SDGs through use of ICT. Therefore, it is beneficial for any society to empower women and ICT is one of the important tools to achieve this objective.

\section{References}

Asongu S., \& Nwachukwu J, C. (2017). "Mobile phone in Diffusion of knowledge and Persistence in Inclusive Human Development in Sub-Saharan Africa.” Journal of Information Development, 33(3), 289-302.

Asongu S., \& Odhiambo N. M., (2018). "ICT, Financial Access and Gender Inclusion in the Formal Economic Sector." African Finance Journal, 22(2), 45-65.

Arellano, M., \& Bover, O., (1995), “Another look at the instrumental variable estimation of error components models", Journal of Econometrics, 68(1), pp. 29-52. Beyond Access, (2012). Empowering Women and Girls 
through ICT at Libraries. Retrieved from www.beyondaccess.net.

Blundell, R. and Bond, S. (1998). Initial conditions and moment restrictions in dynamic panel data models. Journal of Econometrics, 87: 115-143.

Cagatay N. and Ozler S., 1995, "Feminization of the Labor Force: The Effect of Long-term Development and Structural Adjustment." World development, 23(11), 1883-1894.

Chen, D.H.C., 2004. Gender Equality and Economic Development: The Role for Information and Communication Technologies. Policy Research Working Paper Series (3285), The World Bank. Dlodlo N. (2009). "Access to ICT Education for Girls and Women in Rural South Africa: A Case Study.” Technology in Society.31(2), $168-175$.

Efobi U. R., Tanankem B. V., \&Asongu S., (2018). "Female Economic Participation with Information and Communication Technology Advancement: Evidence from Sub-Saharan Africa" South African Journal of Economics, 86(2), 231-246.

G. S. Ogato (2013). The Quest for Gender Responsive Information Communication Technologies (ICT) Policy in Least Developed Countries: Policy and Strategy Implications for Promoting Gender Equality and Women Empowerment in Ethiopia. International Journal of Information Technology and Business Management.Vol.5, No. 1, Pp23-44.

Global Digital Report 2019. Digital 2019: Global Internet Use Accelerates.

Hafkin, N. (2000). Convergence of concepts: Gender and ICT in Africa. Gender and the information revolution in Africa, 1-18.

Hafkin, N., \& Huyer, S. (Eds.) (2006). Cinderella or Cyberella? Empowering women in the knowledge Society. Bloomeld, CT: Kumarian Press.

Islam M. S. (2015). "Impact of ICT on Women Empowerment in South Asia". Journal of Economic and Financial Studies. Vol 3, No. 3, 80-90.

ITU 2017. World Telecommunication Development Report.

Kabeer N. (1994) "Reverse Realities: Gender Hierarchies in Development Thought. London: Verso Publications.

Klasen and Pieters, (2012), "Push or Pull? Drivers of Female Labor Force Participation during India's Economic Boom.” IZA Discussion Paper No. 6395.

Mansell, Robin and Wehn. (1998) "Knowledge Societies: Information Technology for Sustainable Development." Oxford University 1998.

Martin Hilbert. 2010. Digital gender divide or technologically empowered women in developing countries? Women's Studies International Forum, 3(6), 479-489.

Nath, V. (2001). Empowerment and governance through information and communication technologies: women's perspective. The International Information \& Library Review, 33(4), 317-339.

Nikulin, D. (2017). The impact of ICTs on women's economic empowerment. In Catalyzing development through ICT adoption (pp. 15-24). Springer, Cham.

Obayelu A. and Ogunlade, 2006. "Analysis of the Uses of Information Communication Technology (ICT) for Gender Empowerment and Sustainable Poverty Alleviation in Nigeria." International Journal of Education and Development, 2 (3), 45-69.

OECD 2017. "The Pursuit of Gender Equality: An Uphil Battle, OECD.

Ogato G S (2013). The Quest for Gender Responsive Information Communication Technologies (ICTs) Policy in Least Developed Countries: Policy and Strategy Implications for Promoting Gender Equality and Women's Empowerment in Ethiopia. International journal of information technology and business management, 15(1): $23-44$

Perryman L.A., \& Arcos B. L., (2016). "Women Empowerment through Openness: OER, OEP and the Sustainable Development Goals. Open Praxis, 8(2), 163-180.

Roodman, D., (2009). "How to do xtabond2: An introduction to difference and system GMM in Stata", Stata Journal, 9(1), pp. 86-136.

Shehata A. M. H., (2017). "Role of Information and Communication Technology in closing Gender Employment Gap in MENA Countries." The Business and Management Review, 8(4), 168-178.

World Bank (2016). "Digital Dividends," World Development Report 2016. 